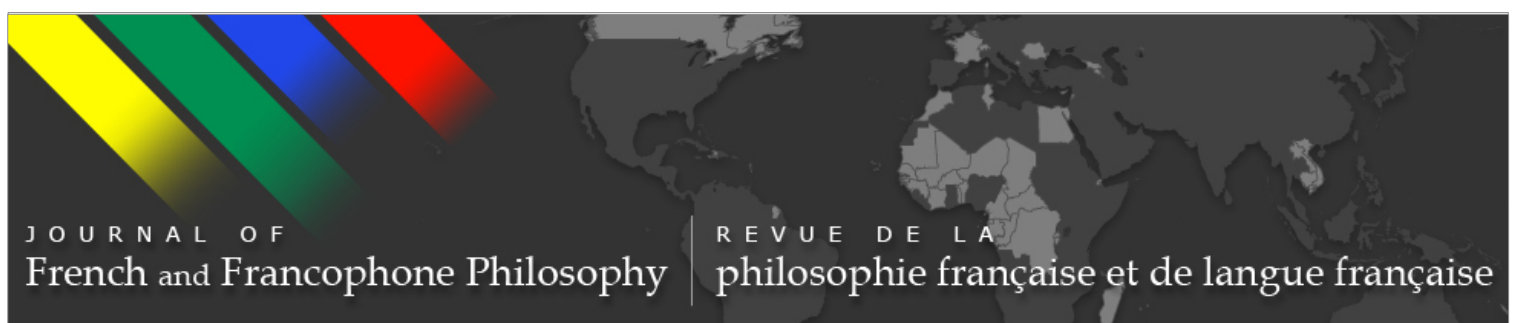

\title{
Julia Kristeva and the Politics of Life
}

\author{
Sarah K. Hansen
}

Journal of French and Francophone Philosophy - Revue de la philosophie française et de langue française, Vol XXI, No 1 (2013) pp 27-42

\author{
Vol XXI, No 1 (2013) \\ ISSN 1936-6280 (print) \\ ISSN 2155-1162 (online) \\ DOI 10.5195/jffp.2013.572 \\ www.jffp.org
}

\section{(oc) BY-NG-ND}

This work is licensed under a Creative Commons Attribution-Noncommercial-No Derivative Works 3.0 United States License.

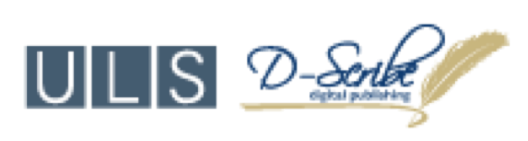

This journal is operated by the University Library System of the University of Pittsburgh as part of its D-Scribe Digital Publishing Program, and is co-sponsored by the University of Pittsburgh Press 


\title{
Julia Kristeva and the Politics of Life
}

\author{
Sarah K. Hansen
}

Drexel University

\section{Introduction: The Mute Symptoms of Contemporary Politics}

In her well-known early trilogy-Powers of Horror (1980), Tales of Love (1983), and Black Sun (1987)_Julia Kristeva describes melancholia as a suffering subjectivity characterized by "the intolerance for object loss" and "the signifier's failure. ${ }^{1}$ Unable to lose and symbolically compensate for the archaic maternal Thing, melancholics suffer from "symbolic collapse"-a slowing down of linguistic activity and a feeling of meaninglessness and despair. To illustrate, Kristeva draws on several case studies from her own clinical practice. For one analysand, Helen, depressive episodes are like a mute living death: "I find myself glued to the spot, as if paralyzed, I lose the ability to speak, my mouth fills with chalk, my mind completely empty. [It is] as if I were dead but I do not think of killing myself, nor do I desire to do so, it is as if it had already been done." ${ }^{2}$ For another analysand, Isabel, pregnancy exacerbates the quiet suffering. Isabel "gives birth for death's sake," entering the life of motherhood in order to exit her own. Her daughter is a "parenthesis within the depression," a "new speech inhibitor in [Isabel's] already not-so-talkative world." ${ }^{3}$ According to Kristeva, a crisis in symbolic law precipitates the quiet failures of Helen and Isabel. A wider notion than civil or criminal law, the psychoanalytic concept of symbolic law refers to the form-giving function of social structures and institutions including language itself; symbolic law supports bodily experiences and semiotic drives in meaningful signifying systems. ${ }^{4}$ Today, loving forms of social support are rare; as bodies silently suffer the disconnection from formgiving law, law itself "suffers" the disconnection of drives and affects.

Kristeva's account of symbolic crisis vis-à-vis melancholia bears a striking resemblance to Giorgio Agamben's account of the "sovereign ban." In Homo Sacer, Agamben describes the ban as an empty law "in force without significance"; the one who has been banned "is not simply set outside the law and made indifferent to it but rather abandoned to it, exposed and threatened" at an ambiguous threshold. ${ }^{5}$ In the fracture between drives and words, the melancholic body is, like the biopolitical

Journal of French and Francophone Philosophy | Revue de la philosophie française et de langue française Vol XXI, No 1 (2013) | www.jffp.org | DOI 10.5195/jffp.2013.572 
body, vulnerably "abandoned to law and remitted to itself." ${ }^{6}$ It is a life "burdened with emptiness," a "flimsy defense" against law's "fierce but artificial" tyranny. ${ }^{7}$ These resonances deepen in Kristeva's more recent three volume series on the "powers and limits of psychoanalysis"-The Sense and Nonsense of Revolt (1996), Intimate Revolt (1997), Hatred and Forgiveness (2005). There, she connects the emptying of symbolic law to the elaboration of regulatory power that reduces subjects to bodies of organs, bios to zoe. Engaging implicitly if not explicitly with biopolitical themes, Kristeva warns that the expansion of regulation produces a "life of death [...a] life for itself, life without questions." 9

This paper explores three aspects of the psychic "life of death": the regulatory powers of the spectacle, the mute symptoms of the patrimonial individual, and the resistance of intimate revolt. Through these discussions, I argue that Kristeva's recent work allows us to explore something like the politics of life, or biopolitics. To be sure, there are tensions between psychoanalysis and the discourse analysis that undergirds most accounts of biopolitics, including the theories of Foucault and Agamben that I examine in these pages. For instance, while Kristeva's recent writing emphasizes the multiplication and depths of disciplinary norms, she maintains that psychic life cannot be the object of total administration; in an important sense, zoe exceeds bios. This paper does not pretend to resolve as much as reflect on these tensions. On my reading, Kristeva's writings on "the powers and limits of psychoanalysis" (1996-2005) explore two themes that are undertheorized in the traditional literature on biopolitics, the regulation of gender and the meaning of life.

\section{The "Power Vacuum": Regulation and the Spectacle}

In her 1996 text The Sense and Nonsense of Revolt, Kristeva describes contemporary power as a kind of disciplinary "power vacuum"normalizing, falsifiable, and non-locatable. ${ }^{10}$ Where the 1980 s trilogy maps the deforming impact of fierce yet artificial law on the preverbal child, the "power vacuum" connects the erosion of symbolic law to the proliferation of norms. Today, "in the place of the prohibition or power that cannot be found, disciplinary and administrative punishments multiply, repressing or rather normalizing everyone." ${ }^{11}$ On this point, Kristeva draws on the writing of French legal theorist Mireille Delmas-Marty, whose research on globalization and human rights law links the "soft laws" of neoliberal deregulation to the expansion of normalizing power. ${ }^{12}$ Delmas-Marty writes of an "anarchical proliferation of norms" by which regulation continues "according to different, less transparent and more complex mechanisms." ${ }^{13}$ Diagnosing a soft symbolic law, Kristeva's own text describes a kind of regulatory avalanche, a disorienting psychic trauma that leaves analysands suffering from a "lack of reference points." 14

Journal of French and Francophone Philosophy | Revue de la philosophie française et de langue française Vol XXI, No 1 (2013) | http://www.jffp.org | DOI 10.5195/jffp.2013.572 
As a falsifiable order, the power vacuum marks how the growth of normalizing power loosens contemporary authority. According to Kristeva, the reduction of law to regulation undermines agencies of power. Open to corruption and perversion, "there are no longer laws but measures [...] susceptible to appeals and delays, to interpretations and falsifications." ${ }^{15}$ Today, legal interpretation amounts to little more than the pursuit of loopholes, to "finding omissions in the law that allow otherwise unlawful acts to be carried out within the terms of the law." ${ }^{16}$ More than substantive codes, crime and transgression reflect (the empty interpretations of) disciplinary tactics. In the place of guilt or innocence, metrics of normality and abnormality, credit and debt, govern social life. As Kristeva puts it, "we no longer speak of culpability but of public menace; we no longer speak of fault (in an automobile accident, for example) but of damages. Instead of responsibility, there is liability [...] crime cannot be found at the same time as prohibition." ${ }^{17}$ Although individuals are no longer culpable, they are held liable by measures that normalize in indirect, re-directable and ultimately, non-locatable ways. Norms are disseminated in regulatory mechanisms yet agents of legitimation are absent or empty masquerades.

Kristeva draws on Guy Debord's notion of the society of the spectacle to discuss the non-locatable (or "invisible") character of the power vacuum. Since disciplinary and regulatory mechanisms are diffuse throughout mass mediated culture, power cannot be located, in part, because a sea of images take up its operation and confirms the absence of authority on every stage, from celebrity judges to the incessant and ever-revising judgment of celebrities themselves. As Kristeva puts it, the spectacle is a pervertible, normalizing "media-friendly" theatre in which "people are increasingly excited when they think they have unearthed a guilty party, a scapegoat" because we live in "a so called liberal society in which there is no surveillance and no punishment except in these theatrically mediatized cases that become a sort of catharsis of the citizen's nonexistent guilt." ${ }^{18}$ In this theatre of blame and shame, power reflects and supports the multiplication of norms and the corruption of authority. The spectacle does not simply frustrate individuals' ability to symbolize and represent psychic trauma, it produces empty docile psyches unable to locate and question authority. ${ }^{19}$

Kristeva's interest in the disciplinary character of spectacles recalls Foucault's divergent discussion in Discipline and Punish. In one of the text's more polemical moments, Foucault observes:

[s]ociety is one not of the spectacle but of surveillance. Under the surface of images, one invests bodies in depth; behind the great abstraction of exchange there continues the meticulous, concrete training of useful forces [...] it is not that the beautiful totality of the individual is amputated, repressed, altered by our social order, it is rather that the individual is carefully fabricated in it,

Journal of French and Francophone Philosophy | Revue de la philosophie française et de langue française Vol XXI, No 1 (2013) | http://www.jffp.org | DOI 10.5195/jffp.2013.572 
according to whole techniques of forces and bodies. We are much less Greeks than we believe. We are neither in the amphitheatre, nor on the stage, but in the panoptic machine. $^{20}$

Here, Foucault describes the spectacle as the "amputating" anachronistic scaffold of sovereign power, suggesting that discipline operates only beyond its field, "under the surface of images" and "behind the abstraction of exchange." Writing in a more mediated and commodifying era than Discipline and Punish, Kristeva's spectacle is not identified with sovereign power. "According to whole techniques of forces and bodies," the spectacle carefully disciplines and shapes the psyche through mass media and consumer culture; where "invisible" power falls short, it facilitates the empty resurgence of law in theatrical scapegoating. The normalizing order is a little more "Greek" than Foucault believes; today the amphitheatre and the panopticon coexist and coordinate.

In this context, Kristeva's claim that "there is no punishment and no surveillance" beyond the spectacle refers to the "so-called liberal" mode of the spectacle, not its borders. In fact, Foucault's account of liberal and neoliberal biopower resonates with the attitude that "anything goes." If discipline "regulates everything" and "lets nothing escape," biopower "lets things happen." ${ }^{21}$ Where discipline holds that "the smallest things must not be abandoned to themselves," biopower "stands back sufficiently so that one can grasp the point at which things are taking place." 22 With its everincreasing importance in daily life, the internet appears an unlimited field of free exploration and self-creation. Yet, "standing back sufficiently" in embedded advertisements and the code of search tools, ever-advancing technologies of user-tracking surveil and shape freedom. This genre of laissez-faire regulation disciplines and scapegoats the abnormal, through the saturation of normalizing images or the mocking circulation of viral videos. But it also presents and promotes an "anything goes" attitude in which normalization parades (and operates) as empty rebellion and fake autonomy. "Letting things happen" without leaving things alone, the "power vacuum" reflects the neo-liberal shape of the spectacle.

In Hatred and Forgiveness, Kristeva applies her understanding of spectacular, normalizing, falsifiable power to the infamous photographs of prisoner abuse at Abu Ghraib prison. Among other horrors, the photographs show U.S. Army officers giving the 'thumbs up' sign over the tortured bodies of Iraqi prisoners, holding bound prisoners with dog leashes, and smiling while mockingly posing as torture victims themselves. On her reading, the images document norms of behavior encouraged inside and outside the U.S. military; at the same time, they are opportunities to "theatrically scapegoat" abnormal and perverse individuals. She exclaims, "never before has the influence of the image over the body laid our sadomasochistic drives bare so lightly: the rule is for robots to have a blast,

Journal of French and Francophone Philosophy | Revue de la philosophie française et de langue française

Vol XXI, No 1 (2013) | http://www.jffp.org | DOI 10.5195/jffp.2013.572 
film themselves, and communicate through the discharge in all innocence!" 23 By describing them as "robots" following "the rule," Kristeva suggests that abusers like Lyndie England and Charles Graner were not exceptions as much as average Americans, "humanoids 'instructed' by television reality shows worldwide and sites on the internet." ${ }^{24}$ To the extent they are "lost sheep," it is only because "the 'society of the spectacle' and the 'deculpabilization of transgression' risks increasing the number of lost sheep." 25 Sadly, Kristeva argues that events like Abu Ghraib are inevitable in the power vacuum where the supportive sites of social life are tenuous or absent and regulation or surveillance multiplies in their place. For all of the attempts to scapegoat particular solidiers, the disciplinary spectacle confirms Susan Sontag's comments about the Abu Ghraib images: "the photographs are us." ${ }^{26}$ In the aftermath of Abu Ghraib, the urgent question is not the scapegoating "who would do this?" but more critically, "who are we?"

\section{The Patrimonial Individual: Entrepreneur or Homo Sacer?}

Kristeva answers the question "who are we?" through her figure of psychic life in the power vacuum, the "patrimonial individual." Reflecting the increasing "primacy of the market economy over the body," she describes the patrimonial individual as "the owner of [their] genetic or organo-physiological patrimony." ${ }^{27}$ When economic measurement applies to one's sense of oneself and to one's body, the figure of a human being with rights is reduced to an owner of organs, and this in the "best case scenario." As Kristeva points out, "there are countries where a person does not even own his own organs" or "where organs are stolen in order to be sold." For the exposed patrimonial individual, "the whole question is whether my patrimony can be remunerated or free: whether I can enrich myself or, as an altruist, forgo payment in the name of humanity or whether I, as a victim, am disposed of it." ${ }^{28}$ These differential courses of economization are reflected in the patrimonial individual's resonance with two representatives of biopolitics-Foucault's entrepreneurial man and Agamben's homo sacer.

The entrepreneur is Foucault's figure of neoliberal biopower, a figure that treats his own life as a perpetual investment opportunity. Making an enterprise of himself, the entrepreneur understands and develops his capacities according to their service in the accumulation of wealth and value. ${ }^{29}$ Kristeva's patrimonial individual highlights the exposed, embodied, psychic dimension of this neoliberal subject. For the patrimonial individual, life as enterprise is reflected in the deformation of early processes of psychic investment. On the successful completion of primary narcissism, the movement of loss, abjection and idealization should culminate in a redirection of psychic investment from the maternal body to language. For Kristeva, this redirection is the "first sublimation, which becomes intrinsic to the human condition": "the investment of signs is translated by a surpassing

Journal of French and Francophone Philosophy | Revue de la philosophie française et de langue française Vol XXI, No 1 (2013) | http://www.jffp.org | DOI 10.5195/jffp.2013.572 
of the depression, by a jubilation [...] ' $\mathrm{I}$ ' do not invest the breast, ' $\mathrm{I}$ ' do not invest mama; ' $\mathrm{I}$ ' invest my own capacity to produce signs." ${ }^{30}$ Reflecting how power conditions transform that which is "intrinsic to the human condition," the patrimonial individual does not accomplish the "first sublimation." In the power vacuum, individuals struggle to effectively invest drives in signs and spiral into rather than surpass depression. ${ }^{31}$ The patrimonial individual makes an enterprise of depression, investing drives in their body, making meaning only in the sense of making market value. According to Kristeva, this venture is a "flimsy" (precarious or risky) defensive relation to a normalizing but falsifiable power. In the best-case scenario, investment can "pay off" as privileged bodies enrich themselves towards better market position. In the worst-case scenario, patrimonial individuals are more deeply caught up in the enterprise of others, their patrimony remunerated, "their organs stolen in order to be sold."

In its potential dispossession, the patrimonial individual also resonates with the bare life of Agamben's homo sacer, a figure whose life is abandoned to law in force without significance and whose death constitutes neither murder nor sacrifice. Divested from the world of signs, the life of the patrimonial individual is not a bios but rather, as Agamben describes bare life, a "bios that is only its own zoe" where zoe is, depending on its politicized market value, "convertible into cash." ${ }^{32}$ Marking the disappearance of a human being with rights, the patrimonial individual is abandoned to a law that is empty but occupied by market logic. Both politicized and economized, the best and worst case scenarios of patrimony hinge on the contingency of market speculation. In the enterprise of life in which bare life is a way of life, "anything goes" in the sense that anything can be sold but not all bodies are valued and values rise and fall. Where Agamben speaks, in relation to bare life, of an inner solidarity between democracy and totalitarianism, Kristeva describes the loss (or economization) of values as a "new version of soft totalitarianism." For Kristeva, "the famous loss of values" threatens to "destroy life after having devalued the question of its meaning." ${ }^{33}$ Producing the bare life of the patrimonial individual, the power vacuum does not support bios - "lives to be told and written," lives that bear and give meaning - as much as it manages zoe - the owners of organs and zoological life. It is this loss of meaning that Kristeva finds so typical and average about the photographs of Abu Ghraib. On her reading the military is a prime example of the psychic trauma of empty regulation, a regulation that more and more characterizes life outside the military. As Kelly Oliver puts it, "this is why young soldiers can follow a strict schedule, polish their boots, and salute their superiors-all codes of extreme discipline-and at the same time, torture and sexually victimize their prisoners and each other. [...] regulations may order the lives of these soldiers, but they don't provide them with robust meaning." 34

Kristeva describes the "new version of soft totalitarianism" in general terms, but she emphasizes that its dangers weigh more heavily on the lives

Journal of French and Francophone Philosophy | Revue de la philosophie française et de langue française

Vol XXI, No 1 (2013) | http://www.jffp.org | DOI 10.5195/jffp.2013.572 
and psyches of women. That is, given the sexed associations of the "ancestral distinction between those who give life (women) and those who give meaning (men)," women experience the totalitarian threat of the power vacuum in disproportionate ways. In so-called liberal society, political and cultural changes promise to support the lives of women as bearing and giving meaning and to help women "give meaning to the act of giving that is life." However, the reversibility of these promises can be observed in the rise of technology and access to contraception and artificial insemination. Today, technology often reduces women to being merely possessors of zoological life; the "control of the birth rate" manages and impoverishes the erotics of sex and the spiritual experience of birth. ${ }^{35}$ In contexts dominated by the supremacy of life as a political and cultural value, the association of women with "those who give life" reflects and encourages the regulation of "wives and mothers [as] natural executors of zoology." More closely tied to life itself, and more readily encountered as a body to be economized, marketed or managed, "those who give life" are often patrimonial women. Here again, the "whole question" is "whether patrimony is remunerated or free," whether one is a victim or beneficiary of dispossession. Among patrimonial women, vulnerability to invasive control and regulation is unevenly distributed. For many, the economization of life sets off the suicidal tendency of melancholia, seeking subjective shelter in market logics that circulate violence. For others, the economization of life sets off the exclusionary tendency of abjection, rejecting and consuming bodies (or body parts) from the lower echelons of society. At the intimate, micropolitical level, these circuits of depression reflect what more typical biopolitical lenses observe at the level of the population: while some women's lives are fostered, others are disallowed or reduced to survival.

To be sure, from the perspective of biopolitics, Kristeva's approach to gender is not without psychoanalytic baggage. At one point in these discussions, she suggests that the vaginal body "imposes on woman an experience of the interior that does not allow it to be easily sacrificed to the prohibition" or molded to the norm. ${ }^{36}$ A kind of excess to the power vacuum, this resistant interior contributes to women's' disproportionate experience of melancholia; women's bios are challenged not only by the empty nature of regulation but the vaginal body itself. Claims like these remind us of the persistent tensions that obtain between psychoanalysis and discourse analysis. ${ }^{37}$ For readers familiar with Kristeva's early work, this account of the vaginal body mirrors her writings on the semiotic body that exceeds, while being shaped by and interrupting, the symbolic order. It is therefore notable that Kristeva's account of resistance in the power vacuum does not mirror her early account of a semiotically driven revolution in poetic language. In the face of a more disseminate and normalizing power Kristeva argues for an intimate revolt rather than a revolutionary poetics.

Journal of French and Francophone Philosophy | Revue de la philosophie française et de langue française Vol XXI, No 1 (2013) | http://www.jffp.org | DOI 10.5195/jffp.2013.572 


\section{Intimate Revolt: Repetition or Resistance?}

In the lead essay of Hatred and Forgiveness, "Thinking about Liberty in Dark Times," Kristeva evokes this intimate revolt within the context of "two visions of freedom or liberty that all democratic societies without exception have elaborated." 38 The first vision is associated with Kant's departure from understandings of freedom as absence from constraint. Kant's Selbstanfang, self-beginning or self-starting, "opens the way for praise of the enterprising individual." ${ }^{39}$ Tracing a broad lineage to neoliberal instrumentalization, Kristeva claims, "this kind of freedom culminates in the logic of globalization and the unrestrained free-market. [It adapts] to the logic of 'causes and effects' that culminates in a specific way of thinking, which is thinking as calculus and scientific thinking. ${ }^{40}$ The second vision of freedom emerges in the pre-Socratic and Socratic world, that is, prior to the Aristotelian categories that condition scientific thought. Rather than a calculating subordination to a cause, the second vision of freedom is a process of "eternal questioning," associated with the Being of Language "which delivers, gives, or presents itself to itself and to the other and liberates itself in the process." ${ }^{41}$ In general, Kristeva describes the second vision as an act of revolt that takes place "in turning back on itself, in accomplishing its anamnesis, in renewing itself continually through a process of self-questioning." 42

By her own admission, Kristeva oversimplifies the contrast between self-beginning and revolt but she does not understate their tensions. Selfbeginning dominates our contemporary vision and threatens the possibility of revolt. The $20^{\text {th }}$ and $21^{\text {st }}$ centuries saw totalitarianisms, soft or otherwise, "appropriate the idea of revolt only to transform it into deadly dogma." 43 Revolutions "liberate" peoples only to squash the process of questioning; normalization parades as rebellion as people forget or fail to question and self-question. 44 "All indications are that we are being carried away by the maelstrom of our calculus thinking and by our consumerism." ${ }^{45}$ In contexts like these, Kristeva asks, "who can revolt, and against what? Can a body of organs revolt against a normalizing order? How? Through remote controlled images? If we want to talk about culture in this context, clarification is necessary: what culture are we talking about?"46

Kristeva's theory of revolt is inspired by its history and etymology. With origins in the Latin verb volvere, to turn or return, the French meaning of revolt is connected to sullying, reversal, detour, cycle, stalling, upheaval, recovery, reassessment among other mutations. ${ }^{47}$ Where "revolution" has associations via revolvere (to consult, to reread, to tell), revolt "twists and turns-indeed, veers off-depending on history." ${ }^{48}$ For Kristeva, "surprise is never extraneous to revolt," especially in Freud's texts where Oedipal revolt plays a central role in psychic and social life. In Freud's well-known fable for the origin of civilization, primitive men live in hordes where the 
father prohibits his son's access to women. One day, in an act of rebellion, the sons murder the father, replace him with the totem symbol, feast and, in their guilt, develop a social bond. For Freud, this murder of the father is an "element of filial rebelliousness" that forms the social order and that emerges, "in the later products of religions, often in the strangest disguises and transformations." ${ }^{49}$ Part of the archaic formation of social life, Oedipal revolt, returns in surprising disguises, twists and turns.

On Kristeva's reading, the most interesting element of the Freudian fable is the "fruit" of the son's crime-the appropriation of the father's qualities and the social bond. The sons identify with and appropriate the father's qualities-authority, law, and value. By taking his place, they displace authority and make it their own. Describing the "fruit" of authorization, Kristeva writes from the first person perspective, " $\mathrm{I}$ ' feel flattered to be promoted to the level of someone who could, if not be the father, at least acquire his qualities, identify with his power; ' $\mathrm{I}$ ' was associated with this power; 'I' was not excluded." ${ }^{50}$ Promoted to one who can, like the father, own authority, the sons "forge the link that will be the socius." ${ }^{51}$ Through identification and authorization they earn a sense of inclusion, a place, in the social order. This social tie is a pleasure "subjacent" to the guilt of the crime; alongside bonding feelings of guilt, the sons feast and celebrate the fruits of revolt. Here, again, Oedipal revolt illustrates the surprise of revolt; displacing and assuming psychic authority, the sons' revolt is an upheaval that reverses and transforms.

Kristeva's notion of "intimate revolt" celebrates a broader practice of revolt that confronts, displaces and assimilates an authority in the psychic economy of the individual. For the developing child, the rebellious incorporation of social authority is a condition for entering the symbolic order. In adult life, intimate revolt is a regenerative return to the past that questions and renews symbolic ties. In each case, revolt is a process of questioning and authorization by which the subject becomes an agent of power and meaning and accomplishes a sense of belonging in social life. Only through revolt can one find and make meaning; its failure marks the onset of the empty docile psyche and its "fruits" lie in the social belonging that enables the capacity to represent. Kristeva describes the rewards of revolt as the "singular autonomy of each, as well as a renewed link with the other." ${ }^{\prime 52}$ Having shown that the psyche is a political and power laden scene, revolt reflects her commitment that the "transformation of man's relationship to meaning [...] intrinsically concerns public life and consequently has profoundly political implications. In fact, it poses the question of another politics, that of permanent conflictuality." ${ }^{25}$ Intimate revolt is not revolutionary. It does not aim to "deliver us" from the political, nor does it imply that the "couch is expected to rise up and take power." ${ }^{54}$ In recognition of the depths and non-locatability of normalizing power, it is 
a "permanent conflictuality" by which drives and affects find support in signifying systems.

As an indefinite, non-punitive, questioning self-relation, intimate revolt bears some resemblance to Foucault's notion of the care of the self. Undertaken by a reflexive subject quite unlike the confessional subject of the first volume of The History of Sexuality, the care of the self is a "moral practice of self-care not a moralized relation to the self"; it is a cultivation of one's potentials, capacities, and strengths rather than a measuring of being vis-àvis higher ideals or hidden truths. ${ }^{55}$ To be sure, Foucault rejects the notion of pre- or extra-symbolic drives and tends to associate psychoanalysis with "spiritual" and "positivist" search for self-truths. ${ }^{56}$ Nevertheless, his writings on the care of the self pursue a self-truth relation that is as intimate as Kristeva's revolt and that is inspired by the same Greek vision of freedom. For both, the reach of regulatory power in modern life means "we can no longer think that access to truth will complete in the subject, like a crowning or a reward." ${ }^{\prime 57}$ Indeed, Kristeva is clear that revolt cannot be finalized. As she puts it, "the interminability, no longer inexorable but open, is a sort of numerical, countable infinity that will continue in the future of a life and generations to come." ${ }^{58}$ Foucault distinguishes between two genres of truth-self relation that embrace this interminability: "the subject is capable of truth, such as it is, but truth cannot save the subject" and the "subject is not capable of the truth, but such as it is, the truth can transfigure and save the subject." ${ }^{59}$ In The Hermeneutics of the Subject, Foucault embraces the first while associating psychoanalysis with the second, more "spiritual" relation. At the same time, he credits Lacan with "reintroducing into psychoanalysis the oldest tradition, the oldest questioning, the oldest disquiet of the epimeleia heautou (care of oneself)." ${ }^{60}$ What would Foucault have said of a disquiet that transfigures but does not save a subject? ${ }^{61}$

\section{Intimate Futures and the Meaning of Life}

Intimate revolt is not a form of salvation; today even its interminable practice is uncertain. Endless questioning is imperiled in the power vacuum where quiet depression is a way of life, a flimsy defensive enterprise that repeats without transfiguring formative traumas. Moreover, another destructive trajectory often overtakes revolt-the eruption of abjection in social life. Abjection is a revolting process in which the infans renders the mother's body abject-disgusting, vomitous, revolting - in order to facilitate maternal separation. It is necessary part of the child's rebellious development; only by abjecting the maternal body can the child begin to confront, displace and assimilate paternal authority. ${ }^{62}$ When authority cannot be located, subjects struggle to abject the maternal body. As Kristeva puts it, when identification with power no longer works "' $\mathrm{I}$ ' feel excluded" in a depressive mode or, in an effort to abolish the feeling of exclusion altogether, "'I' include myself at the top [and] 'I' exclude those at the bottom

Journal of French and Francophone Philosophy | Revue de la philosophie française et de langue française

Vol XXI, No 1 (2013) | http://www.jffp.org | DOI 10.5195/jffp.2013.572 
[...] renewing exclusions at the lower echelons of the social edifice." ${ }^{63}$ Disempowered, excluded and lacking social bonds, a depressed culture experiences (and economizes) the symptoms a depressed individual feels in isolation-despair, symbolic collapse, and a severance of social ties. Subjects in search of a non-locatable authority or a purified social order re-invoke violent processes of identity differentiation against the lower echelons of society. In the absence of resources that give meaning "life becomes a life of death, a life of physical and moral violence, barbarity." ${ }^{64}$ For Kristeva, the explosion of abjection is on display in the barbaric photographs of Abu Ghraib that portray the soldiers' attempts to exclude in order to feel included. Lacking the support of substantive social bonds, the soldiers make "meaning" only by rejecting and victimizing others. ${ }^{65}$ Kristeva's belief that the Abu Ghraib abusers are average Americans is consistent with her view that the future of revolt is uncertain. In Hatred and Forgiveness, she describes revolt as imperiled as it is urgent; at this point, it might only be an aspiration.

To the extent that revolt has any future, Kristeva suggests that it lies in whatever social supports remain in the power vacuum, or the psychic capacities that lie beyond it. Throughout Kristeva's writings, the "loving third" or "imaginary father" is an important figure of loving social support. In the process of separating from the maternal body within primary narcissism, the child identifies with and idealizes the "imaginary father" as the site of the mother's love, an "accepting or loving third" between an abject mother and the stern law of the father. The loving third is a figure of the semiotic element of language, a "conduit that supports the transfer of drives and affects into signification." ${ }^{\prime \prime 6}$ Providing an accepting space for drives in language, the third promises resources to the symbolization of loss and abjection and thereby protects against depressive collapse or abjecting eruptions. Without supportive sites of transference for drives, with only empty laws and regulatory mechanisms, individuals in the power vacuum lose their sense of belonging to the social order, their openness to finding and making meaning.

Although she has long celebrated aesthetic practices and sacred experiences as remainders of the loving third in contemporary life, more recently Kristeva suggests that social programs might help individuals to rediscover their sense of social belonging, their openness to finding and making meaning. As an advocate for individuals with disabilities, Kristeva works with organizations like UNESCO and the National Council on Disability to promote awareness about "people in a situation of handicap," a descriptor that highlights the social context of disabilities. ${ }^{67}$ Describing her advocacy as an extension of her critique of soft totalitarianism, Kristeva navigates the twin challenges of "avoid[ing] euthanasia in the name of science as well as the pseudo-humanism of armoring the patient in the carapace of a worker." ${ }^{\text {"8 }}$ An instrumental, "self-starting" response to 
disability attempts to "build producers" rather than support social connections. Inspired by revolt, Kristeva argues that task lies not in "integration" (or "accommodation") but interaction, "what meaning to give the limits of life-birth, death, deficiencies? [...] Will advanced democracies have the means to support life with its limits and shortcomings, soliciting and favoring the subject within them?"69 Although Kristeva does not identify particular disability programs that support revolt, she does call for a fourth term to be added to the French motto, "Liberty, Equality, Fraternity, and...Vulnerability." Kristeva envisions interactions that share singular vulnerabilities, and support the most fragile aspects of ourselves. In a hopeful moment, she asks "what if this were the private [intimate] face of the politics of disability?"

Kristeva is most hopeful about the future of revolt when she discusses those psychic dimensions that lie beyond the power vacuum. For instance, she claims that the vaginal body gives women an "experience of the interior" that resists regulation. As mentioned above, this resistance is reflected in women's disproportiate experience of depression, but it also manifests as a special capacity for revolt. According to Kristeva, "whether mistress or mother, a woman remains a stranger to the sacrifice: she participates in it, she assumes it, but she disrupts it, she can also threaten it. It is therefore understandable how a vital depth also constitutes a social danger." 71 The particular "social danger" envisaged is the upheaval of a revolt that reconnects life and meaning, refiguring the "ancestral distinction between those who give life (women) and those who give meaning (men)." ${ }^{72}$ A "stranger" to law and regulation, woman suffers from the lack of formgiving social bonds in such a way that she is poised to find and form them anew, beyond the sexist arrangements that associate women with "giving life" and men with "giving meaning."

In biopolitical terms, Kristeva's account of the vaginal body is regulatory. While she celebrates the disappearance of sexist distinctions, this understanding of the vaginal body maintains a distinction between zoe and bios, producing and surveilling the borders of "life itself." Here, Kristeva's text is in tension with itself as much as any biopolitical lens. On the one hand, Kristeva critiques the violence of a normalizing power that produces individuals, in differential and differentiating ways, as depressive enterprising patrimonial men and women that struggle to speak. On the other hand, she tends to link women and zoe to an excess materiality beyond the reach of empty laws and the movements of normalizing power. On the one hand, "life itself, life without questions" is a production of the power vacuum. On the other hand, there is zoe, an excess pure and resistant materiality that precedes and exceeds subjection, the "generally biological aspect of life: which would be as it were 'programmed' [...] by genetic destiny." ${ }^{73}$ From a biopolitical perspective, every appeal to a pre- or extra-

Journal of French and Francophone Philosophy | Revue de la philosophie française et de langue française Vol XXI, No 1 (2013) | http://www.jffp.org | DOI 10.5195/jffp.2013.572 
symbolic life participates in the regulation of women's lives, more than its theorization.

Any attempt to carry forward the thought of the "psychic life of biopolitics" will require critical reflection on the meaning of (psychic) life. This is a reflection that can benefit common and uncommon approaches to biopolitics. In Foucault's texts as well as Agamben's, there is a remarkable ambiguity about the meaning of life and equivocation about life's openness to total administration. In one under-theorized moment of The History of Sexuality, Foucault says that life "constantly escapes or exceeds the techniques that govern and administer it." ${ }^{74}$ While Agamben claims that zoe and bios are always already indistinct in the form of bare life, his theory relies on an understanding of what these terms mean in their distinction. Kristeva's underappreciated engagements with the theme of biopolitics-the power vacuum, the patrimonial individual, intimate revolt-can spur this productive query. On her view, we must revalue the question of life's meaning in order to resist the destructive forces of the power vacuum, and to support the melancholic psyches of Isabel and Helen, Lyndie England and Charles Graner.

1 These works appeared in English in 1982, 1987 and 1989 respectively. Julia Kristeva, Black Sun: Depression and Melancholia (New York: Columbia University Press, 1989), 10.

${ }^{2}$ Kristeva, Black Sun: Depression and Melancholia, 72.

${ }^{3}$ Kristeva, Black Sun: Depression and Melancholia, 89.

4 Kelly Oliver, "Bodies against the law: Abu Ghraib and the war on terror." Continental Philosophy Review 42 (2009): 63-64.

${ }^{5}$ Giorgio Agamben, Homo Sacer: Sovereign Power and Bare Life (Stanford: Stanford University Press, 1995), 28.

${ }^{6}$ Agamben, Homo Sacer, 58- 59.

7 Julia Kristeva, Tales of Love (New York: Columbia University Press, 1987), 387.

${ }^{8}$ These works appeared in English in 2000, 2002, and 2010 respectively.

${ }^{9}$ Catherine Clement and Julia Kristeva, The Feminine and the Sacred (New York: Columbia University Press, 2001), 14. 
10 Julia Kristeva, The Sense and Nonsense of Revolt (New York: Columbia University, 2000) 4.

${ }^{11}$ Kristeva, The Sense and Nonsense of Revolt, 5.

12 Kristeva, The Sense and Nonsense of Revolt, 217n9.

13 Mireille Delmas-Marty, Towards a Truly Common Law (Cambridge: Cambridge University Press, 2002), 103.

14 Julia Kristeva, Revolt, She Said (New York: Semiotext(e), 2002), 32. An interview with Philip Petit originally published as Contra la dépression nationale (Paris: Les Editions Textuel, 1998).

${ }^{15}$ Kristeva, The Sense and Nonsense of Revolt, 5.

${ }^{16}$ Oliver, "Bodies against the law: Abu Ghraib and the war on terror," 67.

${ }^{17}$ Oliver, "Bodies against the law: Abu Ghraib and the war on terror," 5.

${ }^{18}$ Kristeva, The Sense and Nonsense of Revolt, 5.

19 Julia Kristeva, New Maladies of the Soul (New York: Columbia University Press, 1995), 8-9.

${ }^{20}$ Michel Foucault, Discipline and Punish, (New York: Vintage Books, 1995), 217.

${ }^{21}$ Michel Foucault, Security, Territory, Population (New York: Palgrave Macmillan, 2007), 45.

${ }^{22}$ Foucault, Security, Territory, Population, 46.

${ }^{23}$ Kristeva, Hatred and Forgiveness, 176.

24 Kristeva, Hatred and Forgiveness, 175.

${ }^{25}$ Kristeva, Hatred and Forgiveness, 175.

${ }^{26}$ Quoted in Oliver, "Bodies Against the Law: Abu Ghraib and the War on Terror," 70.

${ }^{27}$ Kristeva, The Sense and Nonsense of Revolt, 6.

${ }^{28}$ Kristeva, The Sense and Nonsense of Revolt, 6.

29 See Michel Foucault, The Birth of Biopolitics (New York: Palgrave McMillan, 2008).

30 Foucault, The Birth of Biopolitics, 83.

${ }^{31}$ For a discussion of how oppression in the power vacuum leads to melancholy and depression, see Kelly Oliver, "Social Melancholy and Psychic Space" in The Colonization of Psychic Space (Minneapolis: University of Minnesota Press, 2004), 87152.

32 Agamben, Homo Sacer, 188; Kristeva, The Sense and Nonsense of Revolt, 6.

33 Kristeva, The Feminine and The Sacred, 14 and 13.

34 Oliver, "Bodies Against the Law," 71.

Journal of French and Francophone Philosophy | Revue de la philosophie française et de langue française Vol XXI, No 1 (2013) | http://www.jffp.org | DOI 10.5195/jffp.2013.572 
${ }^{35}$ Kristeva, The Feminine and The Sacred, 13.

${ }^{36}$ Kristeva, The Feminine and the Sacred, 16.

37 John Lechte and Maria Margaroni "Interview: Sharing Singularity" in Julia Kristeva: Live Theory (New York: Continuum Books, 2004), 158

38 Kristeva gave the talk "Thinking about Liberty in Dark Times" on December 3, 2004 upon receiving the Holberg prize from the Crown Prince of Norway. The prize recognizes her "exceptional work" and its "capital importance" in "many disciplines in the human and social sciences." Kristeva, Hatred and Forgiveness (New York: Columbia University Press, 2010), 14.

${ }^{39}$ Kristeva, Hatred and Forgiveness, 14.

40 Kristeva, Hatred and Forgiveness, 15.

${ }^{41}$ Kristeva, Hatred and Forgiveness, 15.

${ }^{42}$ Kristeva, Hatred and Forgiveness, 19.

${ }^{43}$ Kristeva, Hatred and Forgiveness, 19.

${ }^{44}$ Kristeva, Hatred and Forgiveness, 19.

45 Kristeva, Hatred and Forgiveness, 19.

${ }^{46}$ Kristeva, The Sense and Nonsense of Revolt, 8.

${ }^{47}$ Kristeva, The Sense and Nonsense of Revolt, 11.

${ }^{48}$ Kristeva, The Sense and Nonsense of Revolt, 2-4.

${ }^{49}$ Quoted in Ibid, 13.

${ }^{50}$ Kristeva, The Sense and Nonsense of Revolt, 14.

${ }^{51}$ Kristeva, The Sense and Nonsense of Revolt, 23.

52 Kristeva, Intimate Revolt (New York: Columbia University Press, 2002), 8.

53 Kristeva, Intimate Revolt, 11.

54 Gana, 201; Kristeva, The Sense and Nonsense of Revolt, 50.

55 Butler, Giving an Account of Oneself, 128.

${ }^{56}$ Michel Foucault, The Hermeneutics of the Subject (New York: Picador, 2001), 29-

30.

${ }^{57}$ Foucault, The Hermeneutics of the Subject, 18-19.

58 Kristeva, Intimate Revolt, 40. Foucault's description of how "truth cannot save the subject" strikes similar chords. "Knowledge will simply open out onto the indefinite dimension of progress, the end of which is unknown and the advantage of which will only every be realized in the course of history by the institutional accumulation of bodies of knowledge, or the psychological or social benefits to be had from having discovered the truth after having taken such pains to do so. As such, truth cannot save the subject." Foucault, Hermeneutics of the Subject, 19.

Journal of French and Francophone Philosophy | Revue de la philosophie française et de langue française Vol XXI, No 1 (2013) | http://www.jffp.org | DOI 10.5195/jffp.2013.572 
${ }^{59}$ Foucault, The Hermeneutics of the Subject, 19.

60 "Lacan tried to pose what historically is the specifically spiritual question: that of the price the subject must pay for saying the truth, and of the effect on the subject of the fact that he has said, that he can and has said the truth about himself." See Foucault, The Hermeneutics of the Subject, 30.

61 John Toews has argued that psychoanalysis can be understood as a care of the self. See Toews, John E. "Foucault and the Freudian subject: Archaeology, genealogy, and the historicization of psychoanalysis." Foucault and the Writing of History (1994): 116-34. Also, in The Culture of Confession from Augustine to Foucault, Chloë Taylor identifies Kristeva, Guattari and Fanon as psychoanalysts who diverge, in one way or another, from Foucault's characterizations within the first volume of The History of Sexuality. See Taylor, Chloë. The Culture of Confession from Augustine to Foucault (Routledge, 2008).

${ }^{62}$ As Kristeva famously states in Black Sun, "the loss of the mother is the first step on the way to becoming autonomous. Matricide is our vital necessity, the sine-quanon condition of our individuation." Kristeva, Black Sun, 27-28.

${ }^{63}$ Kristeva, Black Sun, 23.

${ }^{64}$ Kristeva, The Sense and Nonsense of Revolt, 7.

${ }^{65}$ Kristeva, Hatred and Forgiveness, 176.

${ }^{66}$ Kelly Oliver, "Revolt and Forgiveness," 83.

${ }^{67}$ Kristeva, Hatred and Forgiveness, 37.

68 Kristeva, Hatred and Forgiveness, 41.

${ }^{69}$ Kristeva, Hatred and Forgiveness, 41.

70 Kristeva, Hatred and Forgiveness, 45.

${ }^{71}$ Kristeva, The Feminine and The Sacred, 16.

72 Kristeva, The Feminine and The Sacred, 14.

73 Lechte and Margaroni, “Interview: Sharing Singularity," 158-159.

${ }^{74}$ Foucault, The History of Sexuality: Volume One, 143.

Journal of French and Francophone Philosophy | Revue de la philosophie française et de langue française Vol XXI, No 1 (2013) | http://www.jffp.org | DOI 10.5195/jffp.2013.572 